\title{
Chromosomal Location of Host Specificity in Salmonella typhimurium
}

\author{
By C. COLSON, ANNE M. COLSON AND ALINE van PEL \\ Laboratoire de Cytogénétique, Institut Carnoy, Université de Louvain, \\ 24 Vaartstraat, Louvain, Belgium
}

(Accepted for publication 7 November 1969)

\begin{abstract}
S UMMAR Y
The chromosomal location of the genes for host specificity in Salmonella typhimurium has been investigated by F-mediated conjugation using host specificity mutants isolated previously. It was found that the sites of mutations leading to two distinct phenotypes, $\mathrm{r}_{\mathrm{LT}}^{-} \mathrm{m}_{\mathrm{LT}}^{+}$and $\mathrm{r}_{\mathrm{LT}}^{-} \mathrm{m}_{\mathrm{LT}}^{-}$, are closely linked to each other and are located near the marker proC.
\end{abstract}

\section{INTRODUCTION}

We have recently isolated a series of mutants of Salmonella typhimurium which are defective in a system of host-controlled restriction and modification that controls the acceptance of foreign phage P 22 DNA and bacterial DNA (Colson, Colson \& van Pel, 1969). These mutants closely resemble those isolated in Escherichia coli $\mathrm{K}$ and B in which recombination and complementation studies have shown that the functions of restriction and modification are governed by a cluster of at least three genes situated at about one time unit to the left of the marker $t h r$ (Colson, Glover, Symonds \& Stacey, 1965; Wood, I966; Glover, 1968; Arber \& Linn, I969; Boyer \& RoullandDussoix, 1969; Glover \& Colson, 1969). In view of the extensive homology observed between the genetic maps of $E$. coli and $S$. typhimurium (Sanderson \& Demerec, I965), one may consider a priori that this locus is a good candidate for the chromosomal location of the host specificity genes in S. typhimurium. On the other hand, the loss of the genetic determinants for host specificity in $S$. typhimurium was first observed in $\mathrm{lac}^{+}$'hybrids' obtained from conjugation experiments between a $\mathrm{Hfr}$ $E$. coli and $S$. typhimurium LT 7 mut (harbouring a mutator gene). Therefore, it was thought that these genetic determinants were lost by exchange of genetic material with $E$. coli in the pro-lac region of the map (Zinder, 1960). However, recent experiments show that crosses between $E$. coli $\mathrm{Hfr}$ and $S$. typhimurium tend to select host specificity deficient mutants in the recipient strain (Colson \& Colson, I967; Okada, Watanabe \& Miyake, 1968).

The experiments presented in this paper define the map position of the genes for host specificity in Salmonella typhimurium by means of bacterial conjugation with host specificity mutants isolated in $\mathrm{F}^{-}$and $\mathrm{Hfr}$ strains. 


\section{METHODS}

Bacteria. The bacterial strains used in this study are listed in Table I, and the map position of the relevant markers is shown in Fig. I.

Media. The media have been described previously (Colson, Colson \& van Pel, I969). Scoring of host specificity phenotype. Restriction and modification were scored with a $c 2$ mutant of phage P22. The restriction test was performed by inoculating small broth cultures of the strains in soft agar overlays on plates and then adding drops of

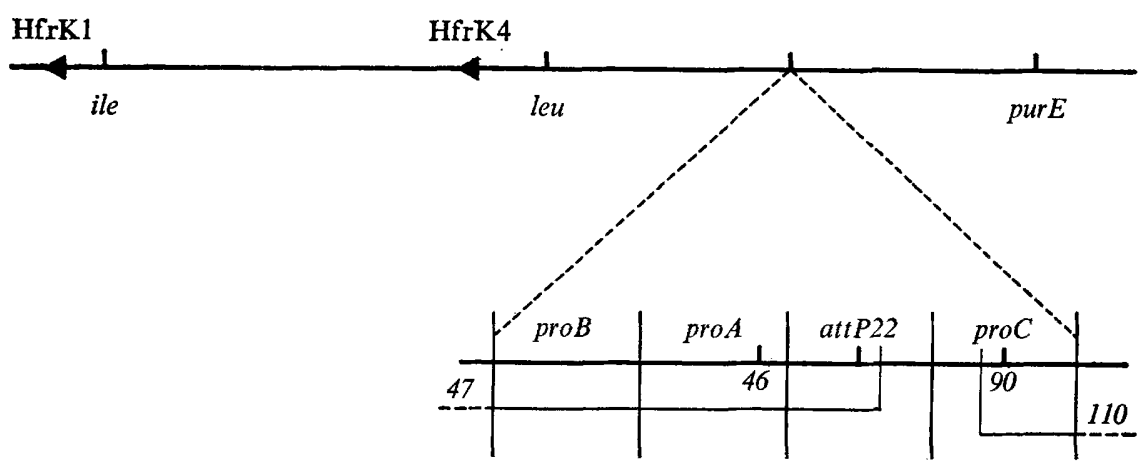

Fig. I. Partial linkage map of Salmonella typhimurium. The point of origin and the direction of transfer by HfrK $I$ and HfrK 4 are indicated by arrows. The details of the pro region are from Itakawa \& Demerec, I968. proA 46 and proC 90 are point mutations, proC 110 is a deletion covering most of pro $C$, pro $A B 47$ is a deletion extending across pro $A, \operatorname{pro} B$, and the attachment site of phage $P 22$ (attP 22). The orientation of the whole pro region with respect to outside markers is not certain (Smith, I968).

Table I. Bacterial strains

\begin{tabular}{|c|c|c|c|}
\hline Symbol & Genotype* & $\begin{array}{l}\text { Host specificity } \\
\text { mutations } \dagger\end{array}$ & Source \\
\hline SA 534 HfrK 4 & $\operatorname{ser} A I_{3}$ & $\begin{array}{l}h s r-5 I \\
h s s-53 \\
h s s-9 I\end{array}$ & K. E. Sanderson \\
\hline SA 464 HfrK I & $\operatorname{serA} I_{3}$ & - & K. E. Sanderson \\
\hline SA 195 & proAB 47 purE 66 & $\begin{array}{l}h s r-113 \\
h s s-8 \\
h s s-617\end{array}$ & K. E. Sanderson \\
\hline SB IO6 & $\begin{array}{l}\text { ile-405 rha-46r leu-I003 } \\
\text { proA-46 purC7 } \text { str-r }\end{array}$ & $h s r-37$ & P. E. Hartman \\
\hline - & proC 90 & $\begin{array}{l}h s r-185 \\
h s s-4 \\
h s s-16 \\
h s s-64 \\
h s s-800\end{array}$ & H. O. Smith \\
\hline - & proC IIO & $\begin{array}{l}h s s-6 \\
h s s-20\end{array}$ & H. O. Smith \\
\hline
\end{tabular}

* The map position of the markers used in this study are indicated in Fig. 1.

$\dagger$ The gene symbols used for host specificity are in agreement with the terminology of Arber \& Linn, 1969. Mutants which have lost the capacity to restrict foreign DNA while retaining the capacity to modify it specifically (phenotype $\mathbf{r}_{\mathrm{LT}}^{-} \mathrm{m}_{\mathrm{LT}}^{+}$) are designated $h s r$. Mutants which have lost both the capacities to restrict and to modify DNA as the result of a single mutation (phenotype $\mathrm{r}_{\mathrm{LT}}^{-m_{\overline{\mathrm{LT}} \mathrm{T}} \text { ) }}$ are designated hss. The isolation and the phenotypic characterization of these mutants have been described previously (Colson, Colson \& van Pel, 1969). 
serially diluted suspensions of P $22 c 2$. LT (having the LT modification) and P $22 c 2.0$ (lacking the LT modification). After incubation, strains able to restrict $\left(\mathrm{r}_{\mathrm{LT}}^{+}\right)$show $1 \mathrm{O}^{4}$ less plaques of $\mathrm{P} 22 \mathrm{c} 2.0$ than of $\mathrm{P} 22 \mathrm{c} 2 . \mathrm{LT}$, while strains unable to restrict $\left(\mathrm{r}_{\mathrm{LT}}^{-}\right)$ accept both phages with the same efficiency. For scoring large numbers of recombinants a quicker method was utilized. Single colonies of the restreaked recombinants were resuspended in drops of buffer and cross-streaked on nutrient agar against streaks of suspensions containing $10^{5}$ plaque-forming units $/ \mathrm{ml}$. of $\mathrm{P} 22 c 2$. LT and $\mathrm{P} 22 c 2$ 2.0. After incubation, $r_{\mathrm{LT}}^{-}$strains show confluent lysis at both phage streaks while $r_{\mathrm{LT}}^{+}$ strains are lysed only by $\mathrm{P} 22 c 2$. LT. The modification test was performed by adding

Table 2. Linkage between ile, leu, pro, and hsr in the cross: $H$ frK I $\times$ SB IO6 ile leu proA hsr-37 str-r

Exponentially growing cultures of the donor and recipient strains were mixed in equal volumes, centrifuged and kept at $37^{\circ}$ for $60 \mathrm{~min}$. without resuspending the pellets. The mixture was resuspended, diluted and plated on selective minimal media containing $100 \mu \mathrm{g} . / \mathrm{ml}$. of streptomycin. The recombinants were purified by single colony isolation on the same media and then tested individually for unselected markers.

$\begin{array}{lccccc}\begin{array}{l}\text { Selected } \\ \text { marker }\end{array} & \text { ile }^{+} & \text {leu }^{+} & \text {pro }^{+} & h s r^{+} & \begin{array}{c}\text { No. of colonies } \\ \text { tested }\end{array} \\ \text { ile }^{+} & - & 6 & 4 & 3 & 97 \\ \text { leu }^{+} & 4 \mathbf{I} & - & 35 & 32 & 99 \\ \text { pro }^{+} & 4 \mathbf{I} & 49 & - & 63 & 99\end{array}$

Table 3. Inheritance of $h \mathrm{sr}^{+}$from $\mathrm{HfrK} \mathrm{I}$ among various classes of recombinants in the leu-pro-purE region

Same procedure as in Table 2, except that the purified recombinants were first classified with respect to the inheritance of unselected nutritional markers before being tested for their restriction phenotype.

\begin{tabular}{|c|c|c|c|}
\hline Recipient strains & $\begin{array}{l}\text { Classes of } \\
\text { recombinants }\end{array}$ & $h s r^{+}(\%)$ & $\begin{array}{c}\text { No. of } \\
\text { colonies tested }\end{array}$ \\
\hline $\begin{array}{l}\text { SB I06 hsr-37 } \\
\text { ile leu proA str-r }\end{array}$ & $\begin{array}{l}\text { leu } \text { pro }^{+} \\
\text {leu pro } \\
\text { leu } \\
\text { leu pro }\end{array}$ & $\begin{array}{l}56 \\
66 \\
23\end{array}$ & $\begin{array}{l}83 \\
50 \\
64\end{array}$ \\
\hline $\begin{array}{l}\text { SA } 195 \text { hsr-113 } \\
\text { proAB purE str-r }\end{array}$ & $\begin{array}{l}\text { pro }^{+} \text {pur } \\
\text { pro } \\
\text { pro pur } \\
\text { pur }\end{array}$ & $\begin{array}{r}97 \\
88 \\
<2\end{array}$ & $\begin{array}{l}99 \\
75 \\
46\end{array}$ \\
\hline
\end{tabular}

drops of serially diluted suspensions of $\mathrm{P} 22 \mathrm{c} 2$ grown on the strain to be tested to plates seeded with soft agar overlays of known $r_{L T}^{+}$and $r_{L T}^{-}$strains. After incubation, an equal number of plaques is observed on both indicators if the phage carried the modification, indicating that the test strain was $\mathrm{m}_{\mathrm{LT}}^{+}$. On the contrary, the phage from a $\mathrm{m}_{\mathrm{LT}}^{-}$strain form $\mathrm{IO}^{4}$ less plaques on the $\mathrm{r}_{\mathrm{LT}}^{+}$indicator than on the $\mathrm{r}_{\mathrm{LT}}^{-}$. For the scoring of a large number of recombinants, this test was simplified by using drops of buffer instead of tubes and calibrated loops instead of pipettes for diluting and spotting the phage suspensions. 


\section{RESULTS}

Mapping the hsr mutation. About 100 ile $^{+}, l^{+} u^{+}$and pro $^{+}$recombinants were selected independently from a cross between HfrK $I$ and the multiple auxotroph SB IO6 recipient strain carrying a presumed $h s r$ mutation (phenotype $\mathrm{r}_{\mathrm{LT}}^{-} \mathrm{m}_{\mathrm{LT}}^{+}$). These recombinants were analysed for the inheritance of unselected donor markers including the wild-type host specificity marker. The results show that $h s r^{+}$is inherited together with $\mathrm{pro}^{+}(63 \%)$ while its linkage to $\mathrm{leu}^{+}(32 \%)$ and $\mathrm{ile}^{+}(3 \%)$ is almost the same as that of $\mathrm{pro}^{+}$to those markers (Table 2). The close linkage of the $h s r$ gene to the pro region was confirmed by the results of two other crosses performed using HfrK I. In the first cross with SB I06 $h s r$, leu ${ }^{+}$and $p r o A^{+}$recombinants were selected while pro $A B^{+}$and pur $E^{+}$recombinants were selected in the second cross to SA I $95 h s r$. From the first cross $l e u^{+}$pro $^{+}$, leu pro ${ }^{+}$and leu ${ }^{+}$pro recombinants were obtained and the inheritance of $\mathrm{hsr}^{+}$was scored among each class of recombinants. Similarly in the second cross pro $^{+}$purt, pro $^{+}$pur and pro pur ${ }^{+}$recombinants were obtained and the inheritance of $h s r^{+}$was scored among each class. In both crosses whenever prot was inherited by the recombinant class the inheritance of $h s r^{+}$was high. When selection was made against the inheritance of pro $^{+}$the inheritance of $h \mathrm{sr}^{+}$was low (Table 3).

In an attempt to locate the site of $h s r$ mutations more precisely with respect to the pro cistrons, two interrupted mating experiments were conducted using HfrK 4 and selecting pro $A^{+}$recombinants in one cross while selecting proC $^{+}$recombinants in the other. Both recipient strains were hsr mutants and the inheritance of $h s r^{+}$was scored among $\mathrm{pro}^{+}$recombinants selected at $2 \mathrm{~min}$. intervals. The percentage of $h \mathrm{sr}^{+}$among pro $A^{+}$increased with the time allowed for transfer, rising to $88 \%$ at a blending time of 36 min., while the percentage of $h s r^{+}$among $p r o C^{+}$was at the maximum level even at the earliest time of blending (Table 4 ). This means that when $h s r^{+}$is transferred by

\section{Table 4. Inheritance of $\mathrm{pro}^{+}$and $\mathrm{hsr}^{+}$in interrupted mating experiments with $\mathrm{HfrK}_{4}$}

I ml. samples of the exponentially growing recipient strains were mixed with equal volumes of I/ ro dilutions of exponentially growing cultures of the donor and the cells were immediately collected by filtration on a millipore filter. The filters were kept for $10 \mathrm{~min}$. on the surface of a soft nutrient agar plate at $37^{\circ}$. The filters were then transferred to large flasks containing $20 \mathrm{ml}$. of prewarmed broth and gently agitated in a shaking water bath at $37^{\circ}$. At intervals, a $\mathrm{I} \mathrm{ml}$. sample was diluted into $9 \mathrm{ml}$. of buffer, shaken vigorously for $30 \mathrm{sec}$. Samples of 0.1 or $0.5 \mathrm{ml}$. of the blended mixtures were added to $3 \mathrm{ml}$. of melted soft agar containing $100 \mu \mathrm{g}$./ $\mathrm{ml}$. of streptomycin and immediately poured over the surface of the selective media containing the same concentration of streptomycin. About $50 \mathrm{pro}^{+}$recombinants from each sample were purified and scored for their host specificity phenotype.

\begin{tabular}{|c|c|c|c|c|}
\hline \multirow{3}{*}{$\begin{array}{l}\text { Time of } \\
\text { blending } \\
\text { (min.) }\end{array}$} & \multicolumn{4}{|c|}{ Recipient strains } \\
\hline & \multicolumn{2}{|c|}{ SB I06 pro $A 46 h s r-37$} & \multicolumn{2}{|c|}{ proC $90 h s r-185$} \\
\hline & $\begin{array}{c}\text { No. of } \\
\text { recombinants } / \mathrm{ml} \text {. }\end{array}$ & $h s r^{+}(\%)$ & $\begin{array}{c}\text { No. of } \\
\text { recombinants } / \mathrm{ml} \text {. }\end{array}$ & $h s r^{+}(\%)$ \\
\hline 24 & $1 \cdot 3 \times 10^{3}$ & 56 & $5.8 \times 10^{3}$ & 90 \\
\hline 26 & $4.3 \times 10^{3}$ & 56 & $8.8 \times 10^{3}$ & $>98$ \\
\hline 28 & $8.0 \times 10^{3}$ & 60 & $2.1 \times 10^{4}$ & 90 \\
\hline 30 & $1 \cdot 5 \times 10^{4}$ & 81 & $3.4 \times 10^{4}$ & $>98$ \\
\hline 32 & $2.0 \times 10^{4}$ & 62 & $6.3 \times 10^{4}$ & 98 \\
\hline 34 & $6.5 \times 10^{4}$ & 78 & $\mathrm{I} \cdot \mathrm{I} \times 1 \mathrm{IO}^{5}$ & 92 \\
\hline 36 & $6.4 \times 10^{4}$ & 88 & $\mathrm{I} \cdot 9 \times 10^{5}$ & 98 \\
\hline
\end{tabular}


HfrK 4 it enters the recipient cell after pro $^{+}$and either before proC ${ }^{+}$or so closely after it that it cannot be separated from it by blending. Thus $h s r$ maps either between pro $A$ and proC or just to the right of proC. In addition, this experiment suggests that the orientation of the pro region is: leu-proB proA proC-purE, since it is the only orientation compatible with the fact that $h s r$ is closer to proC than to proA, while distal to proA when transferred by an Hfr injecting its chromosome in the order leu-pro-purE.

Linkage between hsr and hss mutations. The experiments presented in the previous section involved $h s r$ mutants only. No conclusion can therefore be drawn from them about the chromosomal location of the presumed hss mutation leading to the $\mathrm{r}_{\mathrm{LT}}^{-} \mathrm{m}_{\overline{\mathrm{IT}}}^{-}$ phenotype, although by analogy, one might expect to observe clustering of the genes

\section{Table 5. Host specificity among pro ${ }^{+}$recombinants in crosses between hss and hsr mutants}

\begin{tabular}{|c|c|c|c|c|c|c|}
\hline \multirow{3}{*}{$\begin{array}{c}\text { Expt. no. } \\
\text { I }\end{array}$} & \multirow{3}{*}{$\begin{array}{c}\text { Donors } \\
\text { HfrK } 4 h s s-53\end{array}$} & \multirow{3}{*}{$\begin{array}{l}\text { Recipients } \\
\text { proC } 90 h s r-I 85 \\
\text { pro } A B 47 h s r-I I 3\end{array}$} & \multicolumn{3}{|c|}{$\begin{array}{l}\text { No. of recombinants } \\
\text { with genotype }\end{array}$} & \multirow{2}{*}{$\begin{array}{l}\text { Donor } \\
\text { type }(\%)\end{array}$} \\
\hline & & & $h s s^{+} h s r^{+}$ & $h s r$ & hss & \\
\hline & & & $\begin{array}{l}2 \\
0\end{array}$ & $\begin{array}{l}5 \\
8\end{array}$ & $\begin{array}{l}193 \\
192\end{array}$ & $\begin{array}{l}96 \\
96\end{array}$ \\
\hline 2 & HfrK $4 h s s-9 I$ & $\begin{array}{l}\text { proC } 90 h s r-185 \\
\text { proAB } 47 \text { hsr-II3 }\end{array}$ & $\begin{array}{r}18 \\
\mathrm{I}\end{array}$ & $\begin{array}{l}49 \\
\mathrm{I} 4\end{array}$ & $\begin{array}{r}344 \\
83\end{array}$ & $\begin{array}{l}83 \\
85\end{array}$ \\
\hline 3 & HfrK $4 h s r-5 I$ & $\begin{array}{l}\text { proC IIo hss-6 } \\
\text { proC } 90 \text { hss- } 4 \\
\text { proC } 90 \text { hss-I6 } \\
\text { proC } 90 \text { hss- } 64\end{array}$ & $\begin{array}{l}0 \\
0 \\
0 \\
0\end{array}$ & $\begin{array}{l}35 \\
48 \\
24 \\
38\end{array}$ & $\begin{array}{r}13 \\
2 \\
12 \\
10\end{array}$ & $\begin{array}{l}73 \\
96 \\
66 \\
79\end{array}$ \\
\hline
\end{tabular}

for host specificity in Salmonella typhimurium similar to that found in Escherichia coli. To locate the hss mutation $\mathrm{proC}^{+}$and $\mathrm{proAB}^{+}$recombinants were selected in crosses between $h s s$ mutants of $\mathrm{HfrK} 4$ and hsr mutants of SA 195 and proC 90 . In each cross more than $80 \%$ of the rro $^{+}$recombinants had inherited the donor $\mathrm{r}_{\mathrm{LT}}^{-} \mathrm{m}_{\overline{\mathrm{LT}}}^{-}$phenotype (Expts. I and 2, Table 5). Similarly, in crosses between an hsr donor and hss recipients most pro $^{+}$recombinants expressed the $\mathrm{r}_{\mathrm{LT}}^{-} \mathrm{m}_{\mathrm{LT}}^{+}$phenotype of the donor (Expt. 3, Table 5). This shows that both $h s r$ and hss mutations are closely linked to pro. Moreover, the small number of recombinants expressing wild-type host specificity $(3 \%$ or less) indicates that the sites of the $h s r$ and $h s s$ mutations are closely linked since recombination between them to restore wild-type host specificity is a rare event (Table 5).

Crosses were also performed between an Hfr expressing wild-type host specificity and hss pro recipients. Surprisingly no inheritance of wild-type host specificity among $\mathrm{pro}^{+}$recombinants was observed for most of them (Table 6). Some hss ${ }^{+}$recombinants were found in only two cases (hss-6 and hss-4) and at frequencies of I I and $78 \%$ respectively. These results may reflect the existence of several mutational sites leading to the $\mathrm{r}_{\mathrm{LT}}^{-} \mathrm{m}_{\mathrm{LT}}^{-}$phenotype scattered along the chromosome and in most cases not transferred at a measurable frequency from HfrK 4. Nevertheless, the following observations render this hypothesis unlikely. First, on repetition of the crosses in which a measurable linkage between hss and pro had been observed, the values 
obtained proved to be very variable (less than $2 \%$ instead of I I \% for hss-6 and $8 \%$ instead of $78 \%$ for hss-4, see Table 6 ). This indicates that these linkage values cannot be regarded as a true reflexion of map distances. Second, four hss recipient strains in which the linkage between $h s s$ and pro was variable or absent were crossed with a $h s r$ Hfr. All of them inherited the donor host specificity phenotype at a high frequency among pro $^{+}$recombinants indicating that the hss mutation they carry is closely linked to the hsr mutation (see Table 5).

Table 6. Inheritance of hss ${ }^{+}$from $\mathrm{HfrK}_{4}$ among pro $^{+}$recombinants

\begin{tabular}{|c|c|c|}
\hline Recipient strains & No. of $h s^{+}$ & $\begin{array}{l}\text { No. of colonies } \\
\text { tested }\end{array}$ \\
\hline proC rIo hss-6 & $\begin{array}{r}12 \\
0\end{array}$ & $\begin{array}{r}104 \\
50\end{array}$ \\
\hline proC IIO hss-2O & 0 & 24 \\
\hline proC 90 hss-4 & $\begin{array}{r}78 \\
4\end{array}$ & $\begin{array}{r}100 \\
50\end{array}$ \\
\hline proC 90 hss-16 & $\begin{array}{l}\circ \\
0\end{array}$ & $\begin{array}{r}124 \\
50\end{array}$ \\
\hline proC go hss-64 & $\begin{array}{l}0 \\
0\end{array}$ & $\begin{array}{l}24 \\
50\end{array}$ \\
\hline proC 90 hss-80o & $\begin{array}{l}0 \\
0\end{array}$ & $\begin{array}{r}104 \\
50\end{array}$ \\
\hline pro $A B \quad 47$ hss-617 & $\begin{array}{l}\circ \\
0\end{array}$ & $\begin{array}{l}24 \\
50\end{array}$ \\
\hline proAB 47 hss-8 & 0 & 32 \\
\hline
\end{tabular}

\section{DISCUSSION}

Mapping experiments using F-mediated conjugation in Salmonella typhimurium have shown that the sites of the hsr and hss mutations of the LT host specificity system are very close to each other and map in the vicinity of the marker proC. It must be pointed out that the use of the gene symbols $h s s$ and $h s r$ was dictated only by the close phenotypic resemblance of the mutants in the LT system to those of Escherichia coli $K$ and $B$, and that the experiments presented here give no information about the number and the functions of the genes. However, our experiments enhance the similarity between the $S$. typhimurium LT and the $E$. coli systems in showing that mutations leading to distinct phenotypes are clustered. Crosses between mutants have yielded recombinants between $h s s$ and $h s r$ at a higher frequency than between similar mutants in $E$. coli (Lederberg, I966; Glover \& Colson, 1969). It is thus possible that the genes for the LT host specificity are less clustered than in $E$. coli or, perhaps more likely, it reflects the better resolving power of recombination analysis by conjugation in $S$. typhimurium which results from the lower rate of DNA transfer by S. typhimurium donors (Sanderson \& Demerec, 1965).

On the other hand, our experiments show some differences between Salmonella typhimurium LT host specificity and host specificity in Escherichia coli. The almost complete absence of recombinants expressing the donor type host specificity in crosses between wild-type donors and hss recipients was not observed in similar crosses in 
$E$. coli $\mathrm{K}$ and $\mathrm{B}$. The explanation of this phenomenon remains obscure although the fact that it occurred only in crosses between wild-type donors and hss recipients suggests that this phenomenon may be related to the special situation in zygotes in which the resident DNA is not modified and which have freshly inherited a set of genes governing the ability to degrade this DNA.

The difference in map position between the LT host specificity genes and those of Escherichia coli suggests that this host specificity system may have a different origin. Moreover, experiments to be published have revealed that Salmonella typhimurium harbours another host specificity in addition to the LT system, the genetic determinants of which behave as allelic to those of the $E$. coli host specificities.

\section{REFERENCES}

ARber, W. \& LinN, S. (1969). DNA modification and restriction. Annual Review of Biochemistry $3^{8}$, 467.

BOYER, H. W. \& Roulland-Dussoix, D. (I969). A complementation analysis of the restriction and modification of DNA in Escherichia coli. Journal of Molecular Biology 4r, 459.

Colson, C. \& Colson, A. M. (1967). Host specificity and fertility in Salmonella typhimurium LT 7. Biochemical and Biophysical Research Communications 29, 692.

Colson, A. M., Colson, C. \& van Pel, A. (1969). Host-controlled restriction mutants of Salmonella typhimurium. Journal of General Microbiology 58, 57.

Colson, C., Glover, S. W., Symonds, N. \& Stacey, K. A. (1965). The location of the genes for hostcontrolled modification and restriction in Escherichia coli K-I 2. Genetics 52, 1043.

Glover, S. W. (1968). Host specificity in $\mathrm{F}^{\prime}$ heterogenotes of Escherichia coli. Journal of General Microbiology 53, i.

Glover, S. W. \& Colson, C. (1969). Genetics of host-controlled restriction and modification in Escherichia coli. Genetical Research $\mathbf{1 3}, 327$.

ItAKAWA, H. \& DemereC, M. (1968). Salmonella typhimurium proline mutants. Journal of Bacteriology 95, II 89 .

LEDERBERG, S. (1966). Genetics of host-controlled restriction and modification of deoxyribonucleic acid in Escherichia coli. Journal of Bacteriology 9r, 1029.

OKada, M., Watanabe, T. \& MiYake, T. (1968). On the nature of the recipient ability of Salmonella typhimurium for foreign deoxyribonucleic acids. Journal of General Microbiology 50, 24I.

Sanderson, K. E. \& Demerec, M. (1965). The linkage map of Salmonella typhimurium. Genetics 5r, 897 .

Sмiтн, H. O. (1968). Defective phage formation by lysogens of integration deficient phage P22 mutants. Virology 34, 203.

Woon, W. B. (1966). Host specificity of DNA produced by Escherichia coli: bacterial mutations affecting the restriction and modification of DNA. Journal of Molecular Biology 16, I 18.

ZINDER, N. D. (1960). Hybrids of Escherichia and Salmonella. Science, New York 131, 8I 3. 